\title{
Empirical Study on Characteristics of Students' English Learning Motivation in Local Universities
}

\author{
Shuyan $\mathrm{Xu}^{1, \mathrm{a}}$, Xianhua Yang ${ }^{2, \mathrm{~b}}$ \\ ${ }^{1}$ College of Language and Cultural Communication of Shangluo University, Shangluo, Shaanxi, \\ China \\ ${ }^{2}$ College of Humanities \& Social Sciences of Shangluo University, Shangluo, Shaanxi, China \\ a lorraine2004@163.com, b emery10818@sina.com
}

\begin{abstract}
Keywords: English learning motivation, Local university, College students, Empirical study, Personal development.

Abstract. Based on the questionnaire of college students' English learning motivation developed by Gao Yihong(2000), with 304 college students from some local universities as subjects, the paper aims to discuss the intensity of college students' English learning motivation as well as the most common motivation content, and compare different types of college students' English learning motivation. The results show that the intensities of college students' English learning motivation in local university are above average, which are in the following descending order: personal development, social responsibility, information media, inherent interest, achievement, going abroad and learning situation. The most common five main motivation contents are related to personal development. Undergraduates' intrinsic motivation is significantly lower than that of junior college students. And college students who have done part-time jobs have distinctive higher inherent interest motivation, going abroad motivation, social responsibility motivation, information media motivation than those of students who have no working experiences. The differences of English learning motivation in gender, grade, only child, student status, autoditacte, majors have not been found in this research.
\end{abstract}

\section{Introduction}

Learning motivation has been seen as one of the important factors affecting foreign language learning. It is a kind of inherent process or inner psychological state which stimulates and maintains individual learning activity, and drives learning behavior heading for certain goals. With the increasing problems about college students' learning motivation and the growing needs to enhance their language quality, educators, under modern information technology, have explored their language learning, especially English learning motivation for many years, in the aspects of its type, characteristics, stimulating strategy and cultivation. For research contents, the domestic scholars representated by Gao Yihong and Liu Honggang have made systematic studies on the type, characteristics of college students' English learning motivation[1-3]. With regard to research method and measurement tool, it is represented by college students' English learning motivation questionnaire from Gao Yihong at present, though both Shi Yongzhen (2000) and Zou Huimin (2005) also develop questionnaires for measuring students' English learning motivation[4-5]. The subjects are mainly from undergraduates in key universities. Less attention is paid to undergraduate students in local colleges.

Based on educational environment in local universities, this study aims to provide basis for stimulation and cultivation of English learning motivation in the local universities through its investigation and empirical analysis. Two kinds of questions are cheifly discussed in this paper. To be specific, (1) type and intensity of college students' English learning motivation, and the most dynamic learning content; (2) the difference of students' English learning motivation s in different gender, grade, educational background, the only child or not, part-time job or not and so on. 


\section{Research method}

Subjects: using the random sampling method, this paper collects data from 307 college students from a local college in Shaanxi province in 2009, among which 304 are effective subjects, and the effective rate is $99 \%$. Among the total samples, 127 freshmen, 141 sophomores, 36 juniors have their relative proportions of $41.78 \%, 43.38 \%$ and $11.84 \%$ respectively. It includes 167 students of liberal arts, 85 science students, 52 art students; 48 urban students, 53 township students, 203 rural students; 195 undergraduates, 109 junior college students; 55 boy students, 249 girl students; 43 only children, 261 non-only children; 112 students having working experience, 192 students without working experience; 15 students who have participated in elf-taught examination, 289 students who haven't. Measurement tool: Based on the questionnaire of college students' English learning motivation[6] developed by Gao Yihong(2000), this questionnaire samples college students from 30 universities in 29 provinces, autonomous regions, municipalities directly under the central government, and the questionnaire uses five score, 1 means completely disagree, 5 totally agree. It analyses data factors in 2278 valid questionnaires available, and finally fixes 30 items, 7 dimensions, to be specific, inherent interest motivation (6 items), achievement motivation (5 items), learning situation (5 items), going abroad motivation (3 items), social responsibility (3 items), personal development (5 items), information media (2 items). Research shows that the questionnaire has good reliability and validity. The inner consistency coefficient of the dimensions in the questionnaire is larger than 0.61 except information media factor (0.50), the total internal consistency coefficient is 0.81 . In addition, some questions for the basic information of college students are designed in the questionnaire, such as gender, grade, the only child, student status, subject type, part-time job and autoditacte and so on.

Research procedure and data processing : Subjects are required to read the guiding words carefully, then complete the entire questionnaire according to their own conditions. Questionnaire filling is done in class, which also requires students to fill their ID. And it takes 15 to 20 minutes to finish the whole questionnaire. After questionnaires are taken back, it is required to eliminate invalid ones, use SPSS11.5 to input data, and analyse statistical data of methods such as descriptive statistics, t- test, variance analysis.

\section{Results}

\subsection{The Intensity Comparison and Content Analysis of College Students' English Learning Motivation}

Results in table1 shows that the intensities of college students' English learning motivation in local universities are above average, which are in the following descending order: personal development, social responsibility, information media, inherent interest, achievement, going abroad and learning situation.

Table 1 The Intensity of College Students’ English Learning Motivation

\begin{tabular}{cccccccc}
\hline factors & $\begin{array}{c}\text { Inherent } \\
\text { interest }\end{array}$ & achievement & $\begin{array}{c}\text { Leaming } \\
\text { situation }\end{array}$ & Going abroad & $\begin{array}{c}\text { Social } \\
\text { responsibility }\end{array}$ & $\begin{array}{c}\text { Personal } \\
\text { development }\end{array}$ & $\begin{array}{c}\text { Infomation } \\
\text { media }\end{array}$ \\
\hline value & $3.13 \pm 0.77$ & $3.08 \pm 0.78$ & $2.68 \pm 0.64$ & $2.69 \pm 0.84$ & $3.21 \pm 0.82$ & $3.82+0.72$ & $3.16 \pm 0.88$ \\
\hline
\end{tabular}

Results in table 2 shows that the most common motivation contents are mainly related to personal development, and its frequency is above $60 \%$.

Table 2 The Most Common Motivation Contents

\begin{tabular}{clc}
\hline Order & \multicolumn{1}{c}{ (Items) Contents } & Frequency(\%) \\
\hline 1 & (13) ToleamEnglish well is very important tome, becauseit is a useful tool for & 82.6 \\
2 & communication in today's society & 76.0 \\
3 & (29)English is animportant open sesameto the life forward & 71.4 \\
4 & (14)LeamingEnglish well can givemea sense of achievement & 69.4 \\
5 & (16)Basent English is the symbol of education and cultivation & 60.9 \\
\hline
\end{tabular}




\subsection{Comparison of different college students’ English learnning motivations}

After the comparison of 7 factors and total score, it finds that (1) different education college students are only significantly different in the factor of interest motivation $(\mathrm{p}<0.05)$, in other words, undergraduates' intrinsic motivation is significantly lower than that of junior college students (3.05 $\pm 0.79 ; 3.28 \pm 0.73$ ), there is no clear difference existing in other factors and the total score; (2) College students who have done part-time jobs are strikingly different from those having no working experiences in interest motivation, going abroad motivation, social responsibility motivation, personal development motivation, information media motivation and total score $(\mathrm{p}<0.05)$. To be specific, college students who have done part-time jobs have higher scores than those of students who have not $(3.27 \pm 0.79,3.05 \pm 0.75 ; 2.88 \pm 0.79,2.58 \pm 0.86 ; 3.40 \pm 0.69,3.09 \pm 0.86$;

$3.97 \pm 0.58,3.73 \pm 0.77 ; 3.30 \pm 0.91,3.08 \pm 0.85 ; 22.62 \pm 2.69,21.29 \pm 3.41)$. (3)There are no significant differences in the 7 factors and total score among college students who are only children or non-only children, who are participating in autoditacte or not.

With single factor analysis of variance, comparing the 7 factors and total score of college students English learning motivation varying in grade, subject and residence, the study doesn't find remarkable difference $(\mathrm{p}>0.05)$.

\section{Discussion}

\subsection{The Intensity Comparison and Content Analysis of College Students' English Learning Motivation}

The study results show that there are 7 English learning motivations among local college students, and its intensities are above average, which are in the following descending order: personal development, social responsibility, information media, inherent interest, achievement, going abroad and learning situation. Further study shows that the most common motivation contents are mainly related to personal development. To be specific, 82.6\% students believe that to learn English well is very important to them, 76\% students think that English is an important open sesame to the future life, 71.4\% students hold that learning English well can give them a sense of achievement, $69.4 \%$ students consider that fluent English is the symbol of education and cultivation, 60.9\% students think that based on good English they may find a good job in the future.

The above research results show that, the main driving force of college students' English learning in local universities is not English learning itself, but the disadvantage of English learning for personal development, such as passing examination, getting graduation, etc. It is consistent with the study results from Shi Yongzhen (2000), that is, most of college students' English learning motivation are certificate motives. On the other hand, The research above also shows that local university students get the desire for personal development through English leaning.

\subsection{Analysis of different college students' English learning motivations}

This study results show that college students with different education backgrounds are different in the factor of interest motivation, in other words, undergraduate is lower than junior college students. This is different from existing study results. Theoretically, undergraduates' intrinsic motivation in English learning should be higher than those of junior college students. But such particularity appearing in this research is worth exploring.

This college upgraded to the university in 2006, all aspects of undergraduate education are not yet good enough, and the number of undergraduates is limited. Thus, the university doesn't have a good learning atmosphere for undergraduates. It is slowly developing in the advanced process, and teaching for undergraduates is not fine and to be further developed. The psychological blow caused by this environment when undergraduates in this university are comparing with the ones in other universities, may lead to the decline of their inherent motivation. In contrast, as junior college, it has a long history and rich experience in college education and management. For junior college students, 
they have clear and definite direction for emloyment and further education in future, which may work as the reason for their strong English learning motivation, that is, they have a stronger learning motivation despite the low academic degree.

The study shows that college students who have done part-time jobs are strikingly different from those have no working experiences in interest motivation, going abroad motivation, social responsibility motivation, personal development motivation, information media motivation and total score. To be specific, college students who have done part-time jobs have higher scores than those of students who have no working experiences.

Referring to the reason, it is likely that students who do part-time jobs feel and experience more the importance of English theory and practice in the process of working, thus they have stronger learning motivation.

The differences of English learning motivation varying in gender, grade, only child, student status, autoditacte, majors have not been found in this research. And this shows that these --- gender, grade, only child, student status, autoditacte, majors are not main factors leading to the difference in college students’ English learning motivation.

\section{Conclusion}

This study gets the following conclusion as follows:(1)The intensities of college students' English learning motivation are above average.(2)The intensities of college students' English learning motivation are in the following descending order: personal development, social responsibility, information media, inherent interest, achievement, going abroad and learning situation.(3)The most common motivation contents are related to personal development.(4)Undergraduates' intrinsic motivation is lower than that of junior college students.(5)College students who have done part-time jobs have higher motivation than those of students who have no working experiences.

\section{Acknowledgments}

This research is the Scientific Research Program Funded by Shangluo University (Program No.14SKY-FWDF010) and also the Teaching Reform Program Funded by Shangluo University(Program No.15jyjx112).

\section{References}

[1] Yihong Gao, Lu Liu, and Lime Xiu, Longitudinal Study on English Learning Motivation: Based on Sampling of English Majors in a Comprehensive University, Journal of Tianjin Foreign Studies University, vol.11, pp. 67-73, 2008.

[2] Honggang Liu, ELF Motivations and Autonomy in English Learning: An Investigation of Chinese Non-English Major Undergraduates, Teaching English in Chin ,vol.10, pp. 82-97, 2008.

[3] Lu Liu and Yhong Gao, English Learning Motivation and Self-identity Changes: A Longitudinal Study on Second Year English Majors in a Comprehensive University, Foreign Languages in China,vol.2, pp.40-45, 2008.

[4] Yongzhen Shi, Survey on College Students’ English Learning Motivation. Teaching English in China, vol.4, pp. 8-11, 2000.

[5] Huimin Zou; Zhiyu Cai, Motivation Inclination for Foreign Language Learning: Empirical Study on Chinese College Students. Foreign Language and Literature Studies, PP118-123. vol.6, pp. 118-123, 2005.

[6] Yihong Gao and Yuan Zhao, and Ying Cheng, Motivation Types of Chinese College Undergraduates. Modern Foreign Languages, vol.1, pp.29-38, 2003. 